\title{
MEMPELAJARI TEGANGAN PADA BALOK DENGAN BANTUAN SOFTWARE BERBASIS PERHITUNGAN MATEMATIS DAN VISUALISASI 3 DIMENSI ${ }^{[1]}$
}

\author{
Anang Kristianto $^{[2]}$, Yosafat Aji Pranata ${ }^{[2]}$
}

\begin{abstract}
ABSTRAK
Penelitian pada mahasiswa Jurusan Teknik Sipil U.K.Maranatha menunjukkan sebagian besar kecenderungan gaya belajar mahasiswa adalah active-sensing (41,38\%) serta visual (68,97\%), kondisi ini rupanya sejalan dengan penelitian yang dilakukan oleh Richard Felder sebagai pengembang ILS (Index Learning Style) terhadap mahasiswa teknik Iowa State University yang menyatakan bahwa $63 \%$ mahasiswa adalah active learners, $67 \%$ sensing learner dan $85 \%$ visual learners, kemudian penelitian terhadap mahasiswa Michigan Tech. menunjukkan bahwa 56\% active leaners, 63\% sensing leaners, dan $74 \%$ visual leaners. Secara umum hasil penelitian Felder menunjukkan bahwa 64\% active leaners, $63 \%$ sensing leaners, dan $82 \%$ visual leaners. Penemuan ini setidaknya bisa memberi gambaran yang cukup umum bahwa mahasiswa teknik memiliki kecenderungan gaya belajar yang hampir sama dibeberapa perguruan tinggi.

Mahasiswa dengan gaya belajar active-sensing-visual learners memiliki kecenderungan belajar melalui metode praktis problem-solving, penggunaan banyak gambar, grafik, sketsa sederhana serta aktivitas kelompok dimana mereka diberi kesempatan untuk bertukar pikiran dan bereksperimen. Hambatan pemahaman akan materi yang disampaikan terjadi ketika para mahasiswa dengan kecenderungan gaya belajar seperti ini menghadapi materi mekanika rekayasa yang sulit untuk dibayangkan perilakunya, bahkan untuk materi yang didalamnya terdapat persamaan-persamaan matematis yang sederhana.

Salah satu materi dasar yang diberikan pada matakuliah mekanika bahan adalah tegangan pada balok atau kolom (lentur, aksial, geser, dsb) akibat beban merata, terpusat sentris, terpusat eksentris yang mengakibatkan lentur biaksial, dsb. Penggunaan suatu software komputer berbasis perhitungan matematis dan mampu memvisualisasikan persamaan-persamaan matematik dalam bentuk grafik baik 2D atau 3D seperti MatCad atau MatLab akan sangat membantu mahasiswa memahami konsep dan perilaku tegangan pada balok/kolom.

Beberapa keuntungan penggunaan alat bantu ini adalah secara umum mahasiswa dapat memahami dasar teori, penurunan rumus, perilaku tegangan pada balok dengan lebih baik. Kedua, mahasiswa dapat melihat suatu eksperimen sederhana mengenai perilaku tegangan pada balok dengan visualisasi yang menarik karena kemampuan software ini untuk mengupdate hasil serta tampilan grafiknya secara 3 dimensi secara langsung. Ketiga, seluruh proses mulai dari dasar teori, penurunan rumus serta latihan soal serta visualisasi grafik dapat terdokumentasi dengan baik. Keuntungan-keuntungan diatas sangat membantu mahasiswa dengan gaya belajar active-sensing-visual learners yang mayoritas dimiliki oleh mahasiswa teknik sipil untuk memahami pelajaran mekanika bahan.
\end{abstract}

Kata Kunci : tegangan, active learners, sensing learners, visual learners.

\begin{abstract}
A Study of Maranatha Christian University Civil Engineering Students show that majority of the students are active sensing learner ( $41.38 \%$ ) and visual learner ( $68.97 \%$ ), this is inline with the research done by Richard Felder as the developer Index Learning Style, for Iowa State University Engineering students show that $63 \%$ of the students are active learners, $67 \%$ are sensing learners and $85 \%$ are visual learners. In another research of Michigan Tech. Students show that $56 \%$ are active learners, $63 \%$ are sensing learners, and $74 \%$ are visual learners. The overall result of Felder research
\end{abstract}


shows that $64 \%$ of students are active learners, $63 \%$ are sensing learners and $82 \%$ are visual learners. This study can at least give a general picture that Engineering Students have a same style of learning in some university.

Student that are active-sensing-visual learners prefer to study using practical practice problem solving method, using more pictures, graphs, simple sketch, and group activities were they given the opportunity to discuss and experiments. An obstacle to understand the material that is presented occurs when the students who have this style of learning face difficult topic in engineering mechanics that are difficult to visualize its behavior, even more for material, which contain simple mathematic equations.

One of the basic topics that are given in mechanic of material class is stress on beam or column (bending, axial, shear, etc) due to uniformly distributed load, centric load, eccentric load that cause biaxial bending. The use of computer software based on mathematic counting and able to display mathematic equations in the 2D or 3D graph, software like MatCad or MatLab will greatly help the students to understand the concept and behavior of stress on beam/column.

A few benefit of the use this tool is that generally students are better able to understand basic theory, derivation formula, and the behavior of stress on beam. Secondly, the students are able to see a simple experiment of the behavior of stress on beam with interesting visualization because this software ability to update the result and appearance of the graph to 3D. Thirdly, the whole process from basic theory, derivation formula, exercise and displaying graph could be well documented. The benefit mention above greatly help the students that are active sensing visual learners who are the majority of Civil Engineering to understand mechanic of material.

Keywords : Stress , Active learners, Sensing learners, Visual learners.

\section{PENDAHULUAN}

Salah satu kendala yang dihadapi didalam mengajar mekanika rekayasa adalah keterbatasan dosen memahami gaya belajar mahasiswa, kondisi ini dapat mengakibatkan materi yang disampaikan tidak dapat diterima dengan baik oleh mahasiswa dan pada akhirnya akan mempengaruhi minat belajar serta hasil akhirnya. Pemahaman gaya belajar mahasiswa sudah seharusnya merupakan bagian penting yang perlu mendapat perhatian, beberapa penelitian mengklasifikasikan gaya belajar sudah banyak digunakan seperti MyersBrigs Type Indicator (MBTI) yang mengacu dari teori psikologi Carl Jung model pembelajaran Kolb, The Index of Learning Styles (ILS) yang dikembangkan berdasarkan model pembelajaran Felder-Silverman [Felder, 2005].

Jurusan Teknik Sipil Universitas Kristen Maranatha menggunakan Meyers-Brigs Type Indicator (MBTI) untuk mendapatkan profil gaya belajar mahasiswa, dari hasil kuesioner yang disebarkan [Kristianto, 2004] didapatkan hasil 41.38 \% Extroversion (Active)- Sensing, 34.48\% Extroversion - Intuitive, $17.24 \%$ Reflective - Intuitive dan 6.9\% adalah Reflective - Sensing. Sedangkan cara yang paling dominan didalam menangkap pelajaran adalah $68.97 \%$ Visual, 20.69 \% Auditory dan $10.34 \%$ adalah Kinestetik. Penelitian ini memberikan gambaran umum bahwa mayoritas mahasiswa Teknik Sipil adalah active - sensing (41.38\%) serta visual learners (68.97\%). Richard Felder sebagai pengembang The Index of Learning Styles (ILS) yang telah melakukan penelitian pada beberapa mahasiswa teknik perguruan tinggi mendapatkan data yang hampir sama. Hasil 
penelitian untuk mahasiswa Iowa State adalah 63\% active learners, 67\% sensing learners dan $85 \%$ adalah visual learners, sementara mahasiswa Michigan Tech. menunjukkan data berturut-turut 56\% ( A ) , 63\% ( S ) dan 74 \% ( Vs ). Rata-rata gaya belajar untuk beberapa perguruan tinggi menurut penelitian yang telah dilakukan Felder [Felder, 2005] adalah 64\% (A), 63\% (S) dan 82\% (Vs). Berdasarkan data-data beberapa penelitian ini dapat dikatakan bahwa gaya belajar yang dominan mahasiswa teknik pada umumnya adalah active, sensing serta visual. Pemahaman gaya belajar ini setidaknya memudahkan pengajar untuk menyampaikan materi mekanika rekayasa dengan lebih baik sehingga diharapkan proses belajar menjadi lebih efektif karena informasi diserap dengan baik.

Mekanika merupakan bagian dari sains fisika yang mempelajari gerakan serta fenomena dari kinerja gaya (forces) pada benda (bodies) [Besari, 2004]. Konsep gaya adalah abstrak sekalipun tidak seabstrak matematik tetapi mahasiswa seringkali mengalami kesulitan untuk membayangkan fenomena yang terjadi. Konsep serta penurunan rumusrumus secara matematis didalam mekanika rekayasa perlu dipahami dengan baik tetapi bagi mahasiwa dengan gaya belajar active, sensing dan visual akan mengalami kesulitan memahaminya apabila penyampaiannya jauh dari gaya belajar mereka.

Tulisan pada makalah ini mencoba memberikan beberapa gambaran bagaimana mahasiswa teknik yang pada umumnya memiliki gaya belajar active, sensing dan visual dapat memahami informasi yang diterima pada saat proses pembelajaran berlangsung, sehingga diharapkan memberikan inspirasi bagi pengajar mekanika rekayasa sehingga dapat mempersiapkan materi yang sesuai dengan gaya belajar dominan mereka.

Selain itu akan disajikan contoh penggunaan software berbasis perhitungan matematis dan visualisasi 3 dimensi untuk mempelajari fenomena tegangan pada balok dengan penampang segi empat. Beberapa keuntungan dari penggunaan software ini diharapakan dapat menjawab permasalahan kesulitan memahami pelajaran mekanika rekayasa bagi mahasiswa.

\section{MEMAHAMI GAYA BELAJAR ACTIVE-SENSING-VISUAL}

Klasifikasi model gaya belajar mahasiswa didasarkan pada bagaimana cara seseorang menerima dan memproses suatu informasi yang masuk. Suatu proses mental dimana informasi yang dipahami dapat dikonversikan menjadi suatu pengetahuan dapat dikategorikan menjadi dua yaitu active experimentation dan reflective observation. Active experimentation mencakup melakukan sesuatu dengan informasi yang diterima, mendiskusikan, menjelaskan, atau melakukan percobaan dengan suatu cara. Seorang active 
learners bekerja dengan baik dalam suatu kelompok, senang melakukan eksperimen secara aktif dalam menerima informasi. Diskusi singkat dalam kelompok serta aktivitas problemsolving merupakan kegiatan yang sangat diminati oleh tipe ini dan dapat memberikan hasil yang optimal didalam menyerap materi kuliah yang diberikan.

Didalam teori psikologinya Carl Jung memperkenalkan gaya belajar sensing dan intuition sebagai cara seseorang untuk memahami informasi yang diberikan. Sensing mencakup observasi, pengumpulan data-data dengan indera sementara intuition mencakup persepsi tak langsung dengan imajinasi diluar indera. Setiap orang memiliki dua kemampuan ini tetapi didalam penggunaannya sebagian besar cenderung lebih ke sensing atau intuition. Seorang dengan gaya belajar sensing cenderung menyukai fakta-fakta, data, eksperimen, memecahkan masalah dengan metode standar dan baku, tidak menyukai komplikasi, bagus dalam mengingat fakta-fakta, cenderung hati-hati dan tidak bosan dengan detail. Mahasiswa dengan kecenderungan gaya belajar sensing ini akan menemui kesulitan karena didalam penyampaian materi kuliah mekanika rekayasa biasanya lebih menekankan konsep daripada fakta-fakta dan penggunaan simbol dalam mentransfer informasi dimana hal ini adalah merupakan kecenderungan dari gaya belajar intuitive. Agar tercapai tujuan materi kuliah maka dalam penyampaiannya selain harus menjelaskan mengenai konsep dan teori perlu juga mempresentasikan informasi-informasi konkret seperti data, fakta, fenomena yang dapat diamati oleh indera.

Cara seseorang menangkap informasi juga dapat dikategorikan menjadi 3 yaitu visual (penglihatan, gambar, diagaram, simbol), auditory (suara, kata-kata) dan kinestetik (rasa, sentuhan).

Visual learners mengingat dengan lebih baik informasi yang mereka lihat seperti gambar, foto-foto, diagram, flowchart, film, peragaan .Untuk mengakomodasi gaya belajar visual ini pelajaran mekanika rekayasa dapat disampaikan dengan gambar, diagram, sketsa, untuk menggambarkan proses atau prosedur pengerjaan yang kompleks dapat digunakan flowchart, fungsi matematik dapat digambarkan dalam grafik-grafik yang menarik, alat peraga merupakan sarana yang baik untuk membantu memahami materi.

Pada dasarnya didalam penyampaian materi kuliah mekanika rekayasa tidak harus cenderung mengikuti salah satu gaya belajar, tetapi yang perlu mendapat perhatian adalah bahwa pemahaman gaya belajar yang dimiliki oleh mayoritas mahasiswa teknik yaitu activesensing-visual akan membuat penyampaian materi lebih efektif dan seharusnya dapat memberikan hasil akhir yang lebih baik. 


\section{VISUALISASI TEGANGAN PADA BALOK DENGAN MATHCAD}

Tegangan pada balok merupakan salah satu materi mekanika rekayasa yang harus dipahami dengan baik oleh mahasiswa, materi ini memberikan dasar bagi mahasiswa untuk materi selanjutnya yaitu desain struktur bangunan beton, baja maupun kayu. Untuk mengakomodasi gaya belajar active-sensing-visual maka dalam makalah ini digunakan software Mathcad yang merupakan salah satu software berbasis perhitungan matematis yang dapat menampilkan visualisasi tegangan secara 2D maupun 3D.

Penjelasan mengenai konsep tegangan dapat dimulai dengan memberikan gambargambar atau alat peraga yang berhubungan dengan fenomena tegangan dan regangan yang terjadi pada balok yang mengalami lentur atau geser (Gambar 1).

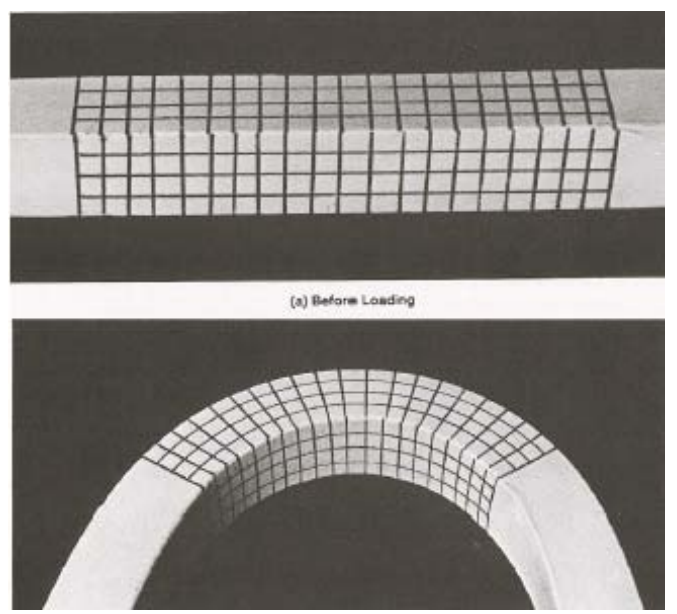

Gambar 1. Contoh Visualisasi Regangan pada Balok

Strategi Aplikasi - Teori - Aplikasi (The A-T-A Method) merupakan salah satu metode yang dapat digunakan bagi mahasiswa sensing yang lebih berorientasi pada detail, fakta daripada konsep yang kompleks dan abstrak. Sebelum penjelasan teori dan penurunan rumus tegangan lentur diberikan, kita dapat memberikan visualisasi aplikasi kasus tegangan lentur yang terjadi pada suatu irisan balok baik secara 2D maupun 3D (Gambar 2) dengan menggunakan Mathcad. Dengan menggunakan software ini kita dapat mengubah-ubah besarnya beban yang mengakibatkan perubahan gaya dalam momen pada balok sehingga perubahan besarnya tegangan yang terjadi dapat diamati oleh mahasiswa secara langsung melalui grafik 3D yang ditampilkan. Eksperimen seperti ini merupakan bagian yang menarik bagi mahasiswa active maupun visual karena mereka dapat melihat fakta-fakta yang terjadi dari eksperimen efek perubahan besarnya beban terhadap tegangan pada penampang. Sekalipun belum mengetahui mengapa persamaan tegangannya seperti itu (karena kita belum menjelaskan konsep serta penurunan rumusnya) tetapi dari visualisasi ini diharapkan mereka mengerti bagaimana hubungan antara variabel-variabel yang mempengaruhi besarnya 
tegangan lentur yaitu momen (M), momen inersia (I) dan jarak titik dari sumbu netral (y). Begitu juga dengan tegangan geser pada suatu penampang, dengan menggunakan grafik 3D mahasiswa dapat melihat bentuk tegangan geser pada suatu penampang dan melakukan eksperimen dengan mengubah-ubah besarnya gaya geser yang diberikan (Gambar 3).

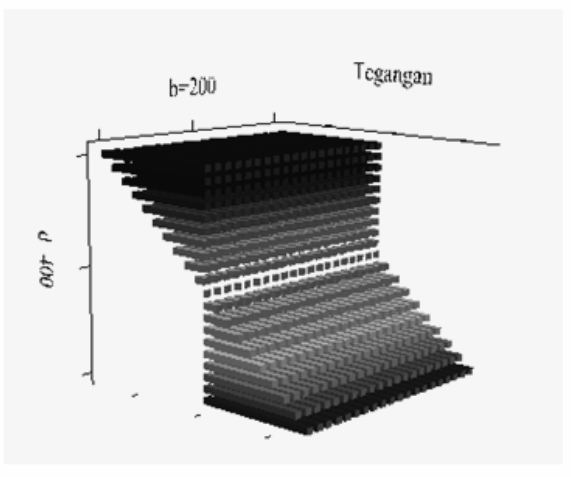

(a). Visualisasi 3D legangan

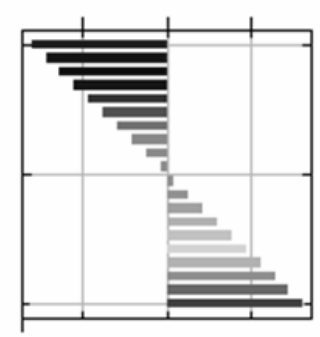

(b). Visualisasi 2D

Gambar 2. Visualisasi tegangan lentur pada suatu penampang balok

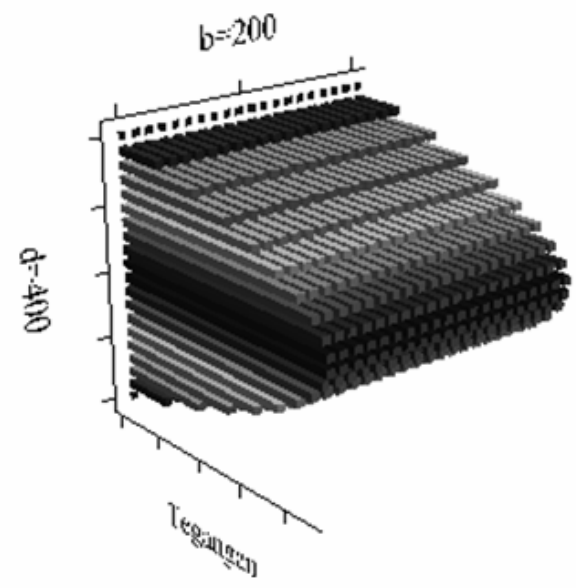

(a). Visualisasi 3D
Tegangan

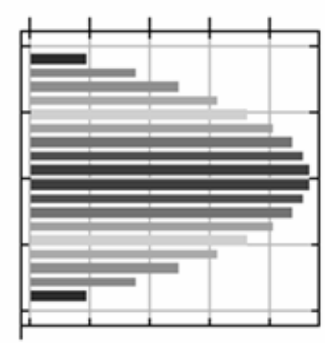

(b). Visualisasi 2D

Gambar 3. Visualisasi tegangan geser pada suatu penampang balok

Visualisasi lainnya yang dapat diberikan adalah kombinasi tegangan aksial dan lentur dua arah. Tanpa menggunakan grafik 3D mahasiswa akan mengalami kesulitan dalam membayangkan resultan tegangan yang terjadi bila ada gaya aksial dan lentur dua arah yang terjadi secara bersamaan. Untuk itu perlu dilakukan bertahap dengan mulai dari visualisasi tegangan akibat beban aksial saja (Gambar 4), akibat momen lentur Mx saja (Gambar 5), akibat momen lentur My (Gambar 6) saja, dan dilanjutkan dengan visualisasi kombinasi pembebanan aksial dan lentur (Gambar 7). 


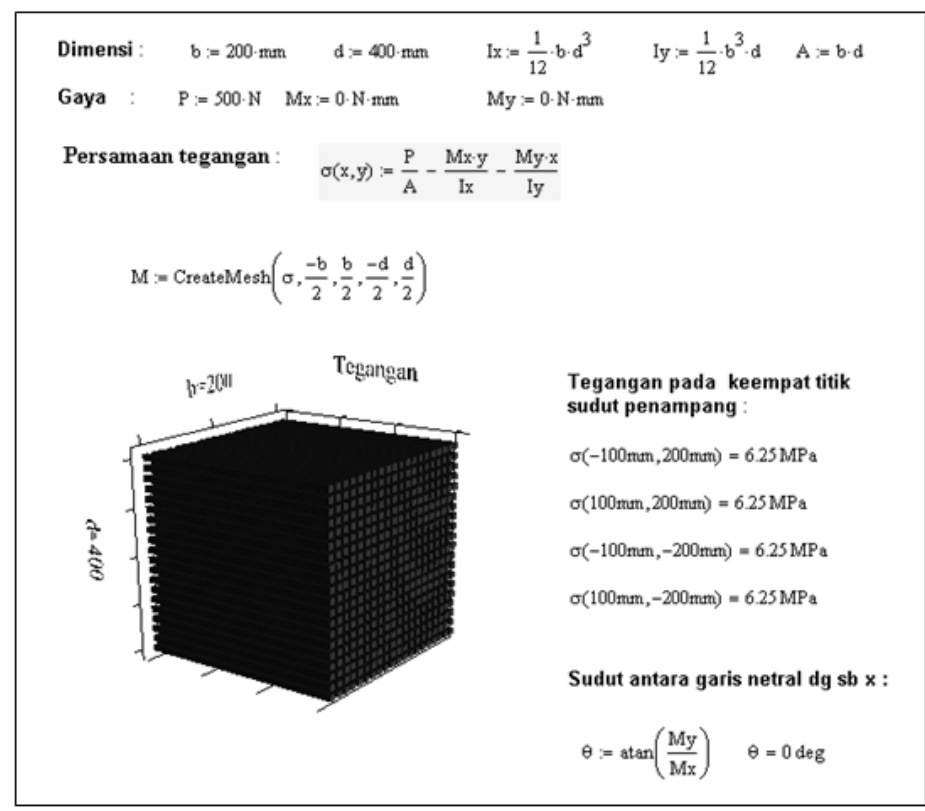

Gambar 4. Visualisasi tegangan pada penampang akibat beban aksial murni

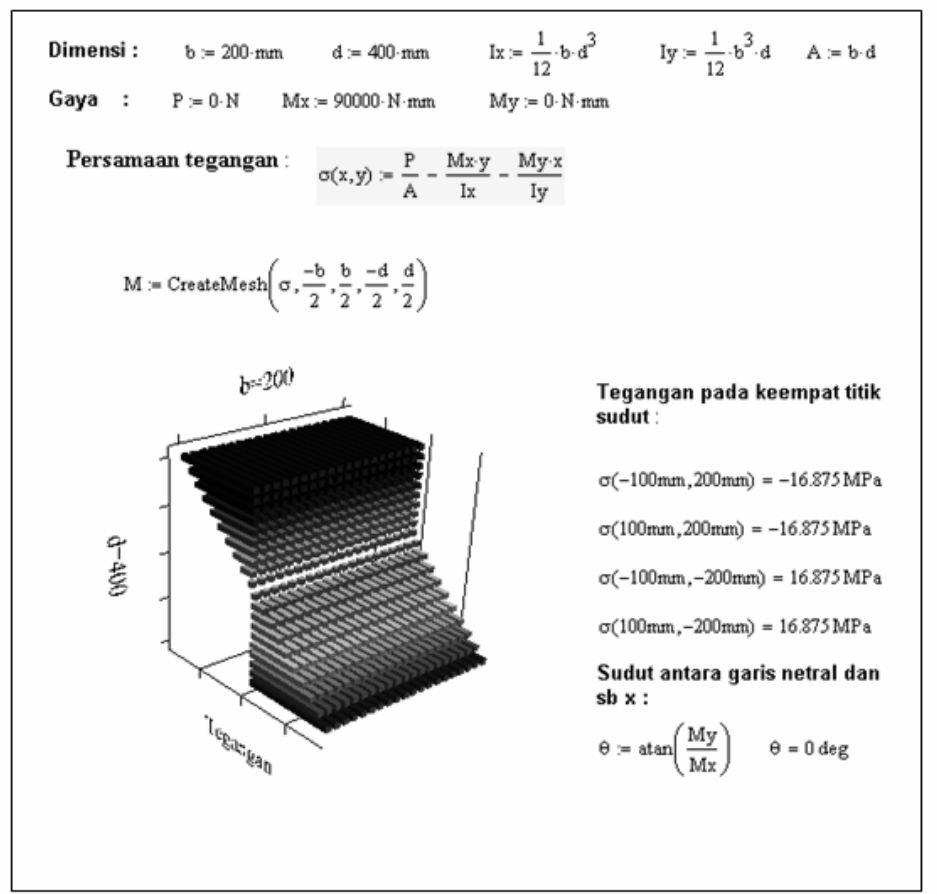

Gambar 5. Visualisasi tegangan pada penampang akibat lentur Mx 


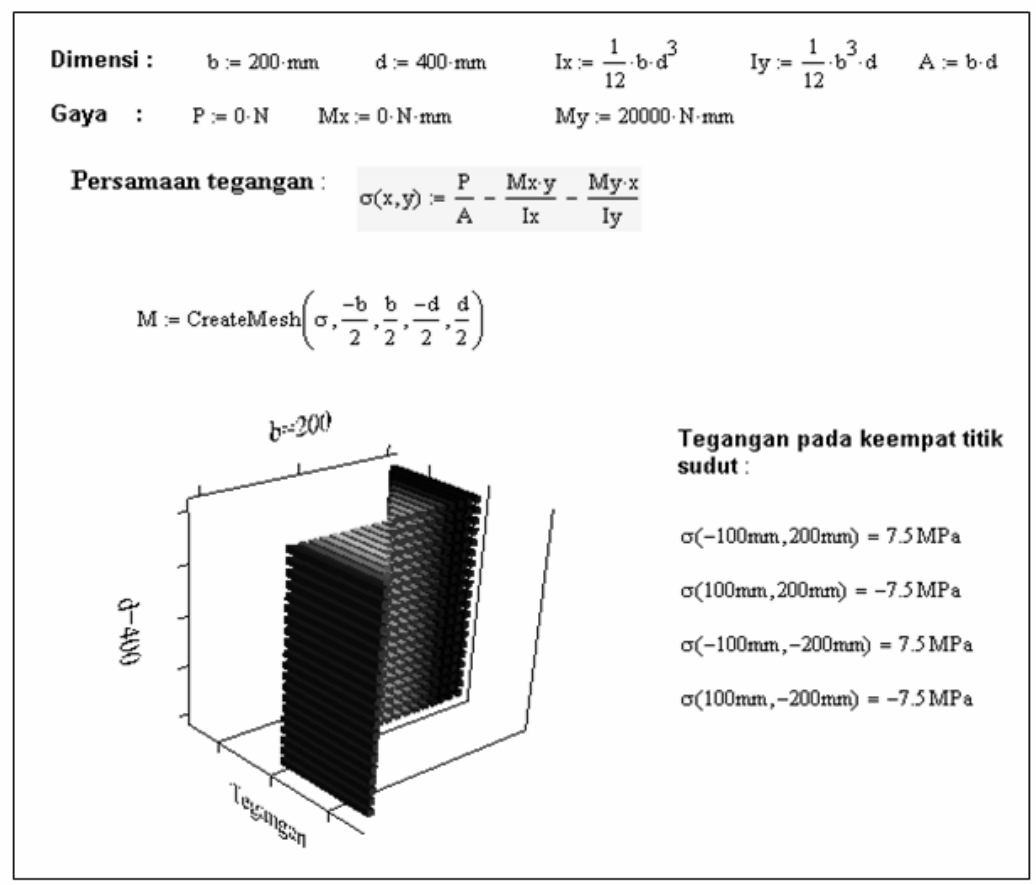

Gambar 6. Visualisasi tegangan pada penampang akibat My

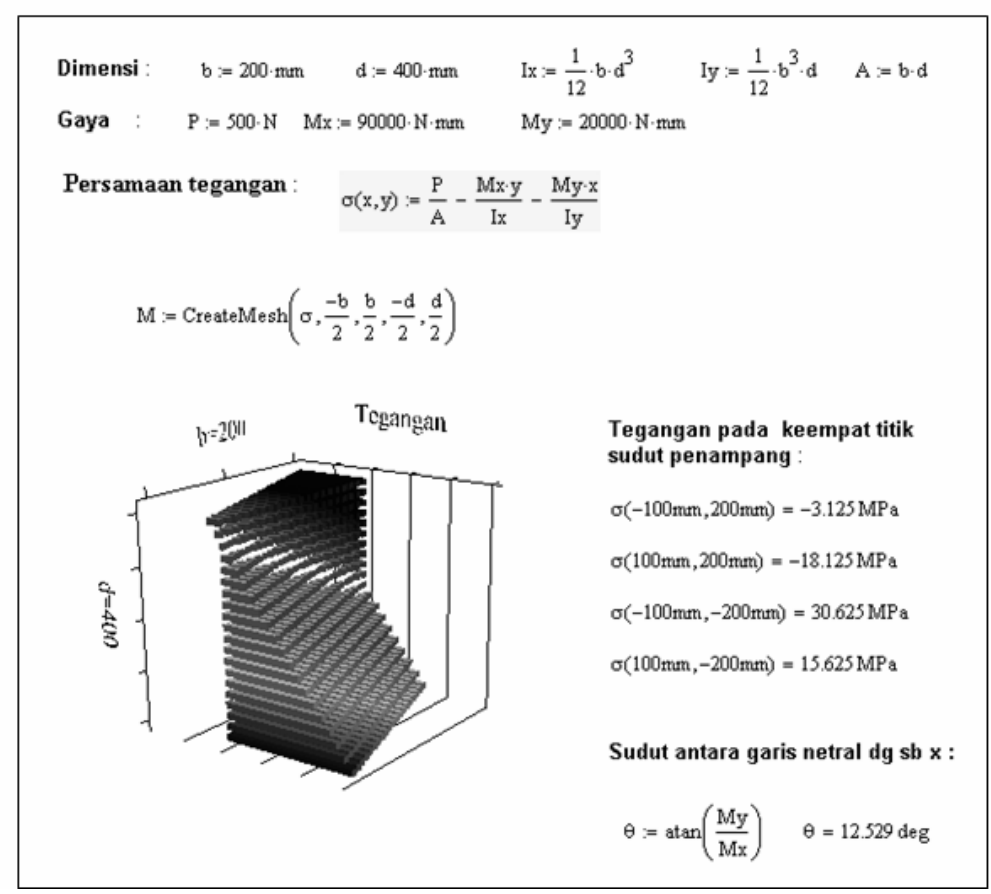

Gambar 7. Visualisasi tegangan pada balok akibat gaya aksial dan momen lentur dua arah

Langkah selanjutnya adalah menjelaskan kepada mahasiswa konsep tegangan dan penurun rumusnya sehingga didapatkan persamaan tegangan lentur maupun geser. Penurunan rumus dan penjelasan konsep tegangan akan lebih mudah dipahami karena 
mahasiswa sudah melakukan eksperimen terlebih dulu. Setelah itu dilanjutkan dengan suatu contoh kasus beserta solusinya. Seluruh proses mulai dari visualisasi kasus - penurunan rumus - contoh kasus serta solusinya dapat dituliskan dalam format software Mathcad sehingga mahasiswa dapat membaca ulang materi yang telah diberikan, selain itu dengan menggunakan software ini seluruh persamaan matematik yang ada dapat langsung dibuat grafiknya (2D maupun 3D) untuk memudahkan mahasiswa melihat perilakunya.

\section{PENUTUP}

Sebagai penutup berikut beberapa hal yang menjadi pokok penting dari tulisan ini adalah :

1. Perlunya memahami gaya belajar mahasiswa teknik pada umumnya yaitu active-sensingvisual, sehingga materi mekanika rekayasa dapat dipahami dengan lebih baik.

2. Pemahaman teori tegangan pada balok bagi mahasiswa dengan gaya belajar activesensing-visual untuk matakuliah mekanika bahan dapat dilakukan dengan bantuan software berbasis perhitungan matematis dan visualisasi grafik 3D (dalam tulisan ini digunakan software MathCAD).

3. Beberapa keuntungan penggunaan alat bantu ini adalah secara umum mahasiswa dapat memahami dasar teori, penurunan rumus, perilaku tegangan pada balok dengan lebih baik. Kedua, mahasiswa dapat melihat suatu eksperimen sederhana mengenai perilaku tegangan pada balok dengan visualisasi yang menarik karena kemampuan software ini untuk mengupdate hasil serta tampilan grafiknya secara 3 dimensi secara langsung. Ketiga, seluruh proses mulai dari dasar teori, penurunan rumus serta latihan soal serta visualisasi grafik dapat terdokumentasi dengan baik.

Tulisan ini diharapkan memberikan inspirasi dalam pengembangan pembelajaran ilmu teknik sipil secara khusus mekanika rekayasa.

\section{DAFTAR PUSTAKA}

1. Besari, M.S. (2004), Pembelajaran Ilmu Mekanika Rekayasa, Prosiding Seminar dan Workshop Nasional Mekanika Rekayasa Teknik Sipil, Universitas Atma Jaya, Yogyakarta, 7-8 Oktober 2004.

2. Kristianto, A. (2004), Mengajar Mekanika Rekayasa dengan Memahami Gaya dan Cara Belajar Mahasiswa, Prosiding Seminar dan Workshop Nasional Mekanika Rekayasa Teknik Sipil, Universitas Atma Jaya, Yogyakarta, 7-8 Oktober 2004. 
3. Felder, R.M., Brent, R. (2005), Understanding Student Differences, Journal of Engineering Education, Vol. 94, Januari 2005.

4. Felder, R.M., Silverman, (1988), Learning and Teaching Styles in Engineering Education, Engineering Education, 78 (7), 674-681, 1988.

5. Green, P.S., Veltri, P., Sputo, T.A., Visualization Tool for Teaching Structural Steel Connection Design, ASEE Southeast Section Conference.

[1] Disampaikan dalam Lokakarya Pembelajaran Mekanika Teknik, Konstruksi Beton dan Konstruksi Baja, Universitas Udayana, Bukit Jimbaran, Bali, 26-27 Juli 2006.

[2] Anang Kristianto, ST., MT., adalah dosen tetap Jurusan Teknik Sipil Universitas Kristen Maranatha, Bandung.

[2] Yosafat Aji Pranata, ST., MT., adalah dosen tetap Jurusan Teknik Sipil Universitas Kristen Maranatha, Bandung. 